\title{
Effect of dietary poppy (Papaver somniferum L.) seed meal supplementation on growth performance, nutrient digestibility, faecal microbiota and blood profile in growing-finishing pigs
}

\author{
S. Muhizi and I.H. Kim ${ }^{1}$
}

Dankook University, Department of Animal Resource Science, Cheonan-si, Chungnam, 31116, Republic of Korea

KEY WORDS: digestibility, growing-finishing pigs, Papaver somniferum, performance traits, poppy seed meal

Received: 18 January 2021

Revised: 2 March 2021

Accepted: 4 March 2021
${ }^{1}$ Corresponding author: e-mail: inhokim@dankook.ac.kr
ABSTRACT. Growth performance, nutrient digestibility, faecal microbiota and blood profile response in growing-finishing pigs fed diet supplemented with poppy (Papaver somniferum L.) seed meal (PSM) were investigated. Sixty crossbred [(Landrace $\times$ Yorkshire $) \times$ Duroc] pigs weighing $25.2 \pm 0.50 \mathrm{~kg}$ were used in the 84-day feeding trial and assigned to two groups: CON - basal diet; and PSM - basal diet + $2 \%$ PSM. Using a randomized complete block design, six replications were arranged according to sex and body weight (BW). The PSM diet significantly increased the average daily feed intake and BW $(P=0.052$ and $P=0.053$, respectively) of pigs during days 57-84 of trial in comparison to $C O N$ diet. In addition, the average daily gain was significantly greater during the last phase and overall experiment $(P=0.045$ and $P=0.042$, respectively) in pigs receiving PSM diet than in those receiving CON diet. Besides, PSM supplementation significantly reduced $(P=0.007)$ feed conversion ratio during the first 28 days in comparison to the CON diet. Also, the digestibility of dry matter in pigs fed the PSM diet was significantly greater at days 56 and $84(P=0.037$ and $P=0.048$, respectively), whereas nitrogen digestibility was unaffected during the whole experiment. However, no significant differences were observed in the faecal microbiota count and blood profile throughout the whole experiment. So, it can be concluded that the PSM can be used in the swine nutrition to improve growth performance and nutrient digestibility.

\section{Introduction}

The global expansion of animal production has driven the increase in the demand for animal feed proteins. Nowadays, plant-derived proteins are considered the most dominant protein source in animal feeding (Patsios et al., 2020). It has been reported that up to $70 \%$ of these proteins are based on soyabean meal (SBM) (Kim et al., 2019). Unfortunately, the SBM has become an unreliable source because of the high demand for such a protein source and consequently, its continuously increasing price (FAS,
2021). This is possibly due to an active competition between human food and animal feed consumptions, especially pig feed, since needs for amino acids in pigs and humans are similar. Therefore, it has become necessary to explore alternatives in protein-rich sources at lower costs. This provoked the nutritionist to put interest in the use of home-grown sources of proteins. Nowadays, several feedstuffs have been explored, such as poppy (Papaver somniferum L.) seed meal (PSM), sunflower meal (SFM), rapeseed meal (RSM), cottonseed meal (CSM), flaxseed meal (FSM), peas, beans and some algae. 
In a previous study by Küçükersan et al. (2009) on laying hens it was demonstrated that the dietary inclusion of different levels of PSM (7.5 and 15\%) has a beneficial effect on feed consumption and egg weight, and a possibility to use PSM as a substitute for SBM due to its high protein contents, encouraging cost and availability in many regions of the world was shown. It was reported that poppy seeds have a high level of crude proteins, crude oil, crude fibre and crude energy and an appreciable amount of major minerals, such as $\mathrm{K}, \mathrm{P}, \mathrm{Ca}, \mathrm{Na}$, and tocopherols and minor minerals, such as $\mathrm{Mn}, \mathrm{Cu}, \mathrm{Mg}$ and $\mathrm{Zn}$ (Özcan and Atalay, 2006). Besides PSM is categorized as oilseed meal rich in polyunsaturated fatty acids (PUFAs) with 73\% linoleic, 10\% palmitic and $13 \%$ oleic acids as major fatty acids (FA) (Nergiz and Ötles, 1994; Azcan et al., 2004).

Statham (1984) found that PSM extract contains $37.8 \%$ crude proteins and $13.1 \mathrm{MJ} / \mathrm{kg}$ dry matter (DM). Fatty acid composition of PSM is more favourable than that of rapeseed oil and FA profile is similar to that of sunflower seed oil (Eklund and Ågren, 1975). Furthermore, growing pigs fed SBM and PSM had a similar growth efficiency with the same lysine:energy ratio (Statham, 1984). In addition, dietary supplementation of PSM had a beneficial effect on feed efficiency, feed consumption and egg production in quails (Coturnix coturnix japonica) (Akinci and Bayram, 2003). Similarly, Bayram et al. (2008) stated that laying hens fed diet with $2.5 \%$ poppy seed oil (PSO) addition were characterised by increased production and quality of eggs. Also, significant changes were observed in the growth performance of broilers fed diet with 10-25\% PSM (Bayram et al., 2006). However, there is very limited evidence on the potential effect of PSM supplementation on growing-finishing pigs. Thus, the aim of the study was to evaluate how growing-finishing pigs would respond to PSM supplemented diet in terms of growth performance, nutrient digestibility, faecal microbiota and blood profile.

\section{Material and methods}

The experiment (DK-4-1611) was carried out at Jeon-ui swine research unit of Dankook University (Republic of Korea). Experimental protocols received approval by the Animal Care and Use Committee of Dankook University. The PSM supplement was commercially purchased from Dodram Feed Mill Co. Ltd. (Icheon, South Korea).

\section{Experimental design, animals, housing and diets}

Sixty 9-week old crossbred [(Landrace $\times$ Yorkshire $) \times$ Duroc] pigs with average body weight $(\mathrm{BW})$ of $25.2 \pm 0.50 \mathrm{~kg}$ were used in the 84-day feeding trial. Pigs were divided into one of two dietary treatments: CON - basal diet, and PSM - basal diet $+2 \%$ PSM. Six replications were arranged concerning sex and BW, 5 animals in each replicate (3 gilts and 2 castrated barrows) in a randomized complete block design. The maize and SBM-based diet was formulated to meet or exceed the nutritional requirements of the National Research Council (NRC, 2012) (Table 1) and fed as a mash. The nutritional composition of PSM is presented in Table 2. The experiment was divided into 3 phases: phase I (days 0-28), phase II (days 29-56) and phase III (days 57-84). Pigs were kept indoors where internal environmental conditions were controlled easily. Every pen was furnished with unlimited access to feed and water all over the 84-day feeding trial.

Table 1. Composition of basal diet (CON) and diet supplemented with poppy seed meal (PSM) fed to growing-finishing pig (as fed-basis)

\begin{tabular}{|c|c|c|c|c|c|c|}
\hline \multirow[t]{2}{*}{ Indices } & \multicolumn{2}{|c|}{$\begin{array}{l}\text { Phase I } \\
\text { (days 0-28) }\end{array}$} & \multicolumn{2}{|c|}{$\begin{array}{l}\text { Phase II } \\
\text { (days 29-56) }\end{array}$} & \multicolumn{2}{|c|}{$\begin{array}{l}\text { Phase III } \\
\text { (days 57-84) }\end{array}$} \\
\hline & $\mathrm{CON}$ & PSM & CON & PSM & CON & PSM \\
\hline \multicolumn{7}{|l|}{ Ingredients, \% } \\
\hline maize & 73.99 & 973.45 & $5 \quad 74.0$ & 273.49 & 75.44 & $4 \quad 74.94$ \\
\hline $\begin{array}{l}\text { soyabean meal } \\
(48 \%)\end{array}$ & 21.31 & $1 \quad 20.25$ & $5 \quad 17.5$ & $0 \quad 16.43$ & 314.88 & $8 \quad 13.80$ \\
\hline wheat & - & - & 4.0 & 4.00 & 6.00 & 6.00 \\
\hline $\begin{array}{l}\text { poppy seed } \\
\text { meal }\end{array}$ & - & 2.00 & - & 2.00 & - & 2.00 \\
\hline tallow & 1.78 & 1.46 & $1.7 \xi$ & 1.46 & 1.50 & 1.17 \\
\hline DCP & 1.24 & 1.2 & 1.2 & 1.20 & 0.73 & 0.68 \\
\hline limestone & 0.75 & 0.7 & 0.6 & 0.58 & 0.70 & 0.66 \\
\hline salt & 0.20 & 0.2 & 0.2 & 0.20 & 0.20 & 0.20 \\
\hline lysine (78\%) & 0.42 & 0.43 & 0.3 & 0.34 & 0.28 & 0.29 \\
\hline $\begin{array}{l}\text { methionine } \\
(99 \%)\end{array}$ & 0.06 & 0.05 & 0.0 & 0.05 & 0.02 & 0.01 \\
\hline vitamin premix ${ }^{1}$ & 0.12 & 0.12 & 0.1 & 0.12 & 0.12 & 0.12 \\
\hline mineral premix ${ }^{2}$ & 0.10 & 0.10 & 0.1 & 0.10 & 0.10 & 0.10 \\
\hline choline $(25 \%)$ & 0.03 & 0.03 & 0.0 & 0.03 & 0.03 & 0.03 \\
\hline \multicolumn{7}{|l|}{ Calculated values } \\
\hline crude protein, $\%$ & $6 \quad 16.50$ & 16.50 & 15.0 & 15.00 & 14.00 & 14.00 \\
\hline $\mathrm{ME}, \mathrm{kcal} / \mathrm{kg}$ & 3300 & 3300 & 3300 & 3300 & 3300 & 3300 \\
\hline Lys, \% & 1.12 & 1.12 & 0.9 & 0.95 & 0.84 & 0.84 \\
\hline Met, \% & 0.32 & 0.32 & 0.3 & 0.30 & 0.25 & 0.25 \\
\hline $\mathrm{Ca}, \%$ & 0.66 & 0.66 & 0.6 & 0.59 & 0.50 & 0.50 \\
\hline $\mathrm{P}, \%$ & 0.56 & 0.56 & 0.5 & 0.55 & 0.45 & 0.45 \\
\hline
\end{tabular}

$\mathrm{DCP}$ - digestible crude protein, ME - metabolizable energy; ${ }^{1}$ provided per kg of complete diet: $\mathrm{mg}$ : vit. $\mathrm{A} 1.3$, vit. $\mathrm{D}_{3} 0.022$, vit. $E .45$, vit. $\mathrm{K}_{3} 4.2$, vit. $B_{5} 24.6$, vit. $B_{2} 8.6$, vit. $B_{12} 0.04 ;{ }^{2}$ provided per $\mathrm{kg}$ of complete diet: mg: Cu 15, Fe 80, Zn 56, Mn 73, I 0.3, Co 0.5, Se 0.4 
Table 2. Nutritional composition of poppy seed meal

\begin{tabular}{lc}
\hline Indices & Amount \\
\hline Tryptophan & 0.38 \\
Threonine & 0.98 \\
Serine & 1.20 \\
Proline & 0.93 \\
Valine & 1.19 \\
Isoleucine & 0.89 \\
Leucine & 1.61 \\
Tyrosine & 0.91 \\
Methionine & 0.74 \\
Cystine & 0.59 \\
Lysine & 1.22 \\
Glycine & 1.21 \\
Alanine & 1.11 \\
Arginine & 2.39 \\
Glutamic acid & 5.85 \\
Aspartic acid & 2.32 \\
Histidine & 0.69 \\
Phenylalanine & 1.03 \\
Starch & 1.04 \\
Acid detergent fibre (ADF) & 21.78 \\
Neutral detergent fibre (NDF) & 23.75 \\
Acid value, KOH/g & 150.09 \\
Peroxide value, meq/kg & 14.05 \\
Ca & 1.38 \\
P & 0.99 \\
Water & 9.38 \\
Crude protein & 27.34 \\
Crude fat & 22.59 \\
Crude fibre & 11.90 \\
Crude ash & 8.47 \\
\hline & \\
& \\
&
\end{tabular}

\section{Sampling and measurements}

Individual BW was noted at the beginning of the experiment and at the end of each phase (days 28, 56 and 84). Feed consumption and residual were weighed and recorded on a pen basis to monitor average daily gain (ADG) and average daily feed intake (ADFI) throughout the whole experiment. The diet was mixed with chromic oxide $(2 \mathrm{~g} / \mathrm{kg})$ as an indigestible marker to allow the determination of $\mathrm{DM}$ and nitrogen $(\mathrm{N})$ digestibility. The digestibility was calculated as follows:

$$
\mathrm{N} \text { digestibility }=1-[(\mathrm{Nf} \times \mathrm{Cd}) /(\mathrm{Nd} \times \mathrm{Cf})],
$$

where: Nf - nutrient concentration in faeces, $\mathrm{Nd}$ - nutrient concentration in diet, $\mathrm{Cd}$ - chromium concentration in diet, and $\mathrm{Cf}-$ chromium dioxide concentration in faeces.

Pigs were fed a chromium-mixed diet one week before collecting the fresh faecal samples. At least 2 pigs per pen (in total 24 pigs) were randomly selected for sampling over the 3 separate collection periods at the end of each phase (days 28, 56 and 84 ). All fresh faecal and feed samples were kept at $-20{ }^{\circ} \mathrm{C}$ until analyses. Before analysis fresh faecal samples were kept at $60^{\circ} \mathrm{C}$ for $72 \mathrm{~h}$ in a forced-air oven to dry and finely minced in a grinder (Shinil, SMX-M41KP, Seoul, South Korea) to pass through a 1-mm screen. Nitrogen was analysed with the use of a Kjectec 8600 analyzer (Foss Tecator AB, Hoeganaes, Sweden) and DM according to the procedure (method 930.15) of the AOAC International (AOAC International, 2010). Chromium was analyzed through UV absorption spectrophotometry (Shimadzu UV-1201, Shimadzu, Kyoto, Japan).

Fresh faecal samples were directly collected using rectal massage techniques from 2 pigs in each pen on days 28,56 and 84 of the experiment for faecal microbial count analysis. One gram of faecal sample from each pen was diluted with $9 \mathrm{ml}$ of $1 \%$ peptone broth (Becton, Dickinson and Company, Franklin Lakes, NJ, USA) and evenly mixed. Total viable counts of bacteria in faecal samples were found out by plating the ten-fold serial dilutions onto MacConkey agar plates (Difco Laboratories, Detroit, MI, USA) and Lactobacilli medium III agar plates (Medium 638, DSMZ, Braunschweig, Germany) to isolate both Escherichia coli and Lactobacillus, respectively. Lactobacilli medium III agar plates were kept in an incubator at $39{ }^{\circ} \mathrm{C}$ for $48 \mathrm{~h}$ under anaerobic conditions and MacConkey agar plates were kept in an incubator at $37^{\circ} \mathrm{C}$ for $24 \mathrm{~h}$. The numbers of $E$. coli and Lactobacillus colonies were counted immediately after plates were removed from the incubator. The concentration of microflora was finally expressed as $\log _{10} \mathrm{CFU} / \mathrm{g}$ of faeces.

Two pigs ( 1 barrow and 1 gilt) were randomly selected from 4 pens of each treatment at days 28 , 56 and 84 and bled via jugular venipuncture using a sterile needle. Blood samples were added into a $\mathrm{K}_{3}$ EDTA vacuum tube (purple top) for subsequent analysis (Becton Dickinson Vacutainer Systems, Franklin Lakes, NJ, USA). Protein, glucose, white blood cells (WBC), red blood cells (RBC) and lymphocytes concentrations in whole blood samples were analyzed using an automatic blood analyzer (ADVIA 120; Bayer, Tarrytown, NY, USA).

\section{Statistical analysis}

All data were statistically analysed using the student's t-test in SAS software (SAS ver. 9.4, 2014; SAS Institute Inc., Cary, NC, USA). The pen served as the experimental unit. The data are presented as the means \pm standard error of mean (SEM). Values of $P<0.05$ were taken to denote statistical significance. 


\section{Results and discussion}

It has been speculated that PSM started to be explored as a feed supplement in modern animal feeding since last few decades. Feed supplements are usually used to achieve the overall growth, health and wellness of animals. Poppy seed meal is known for its protein-rich content (Statham, 1984). Despite its relentless increase in world production, there are increased concerns about poppy seed trade which may be due to international regulation and control of poppy seeds trade (UN, 1999).

Pigs receiving the diet with PSM addition had significantly greater BW and ADFI $(P=0.052$ and $P=0.053$, respectively) during days $57-84$ in comparison to those fed CON diet. In addition, ADG significantly increased during days $57-84$ and in overall experiment $(P=0.045$ and $P=0.042$, respectively) in pigs receiving PSM-supplemented diet in comparison to those receiving $\mathrm{CON}$ diet (Table 3). In addition, PSM supplementation significantly reduced $(P=0.007)$ feed conversion ratio (FCR) during the first 28 days of the trial. This outcome may be attributed to the synergic

Table 3. Effect of dietary supplementation of poppy seed meal on growth performance of growing-finishing pigs

\begin{tabular}{|c|c|c|c|c|}
\hline \multirow{2}{*}{ Indices } & \multicolumn{2}{|l|}{ Treatments $^{1}$} & \multirow{2}{*}{ SEM } & \multirow{2}{*}{$P$-value } \\
\hline & $\mathrm{CON}$ & PSM & & \\
\hline \multicolumn{5}{|l|}{ Body weight, $\mathrm{kg}$} \\
\hline initial & $25.25 \pm 0.82$ & $25.25 \pm 0.79$ & 0.03 & 0.945 \\
\hline days $0-28$ & $42.88 \pm 1.29$ & $44.66 \pm 1.55$ & 0.25 & 0.706 \\
\hline days $29-56$ & $64.68 \pm 1.82$ & $69.95 \pm 2.16$ & 0.34 & 0.714 \\
\hline days $57-84$ & $86.80 \pm 2.37$ & $88.76 \pm 2.91$ & 0.64 & 0.053 \\
\hline \multicolumn{5}{|c|}{ Phase I, days $0-28$} \\
\hline$A D G, g$ & $630 \pm 18$ & $693 \pm 28$ & 9 & 0.337 \\
\hline ADFI, $g$ & $1622 \pm 38$ & $1664 \pm 20$ & 19 & 0.162 \\
\hline FCR & $2.577 \pm 0.018$ & $2.399 \pm 0.078$ & 0.049 & 0.007 \\
\hline \multicolumn{5}{|c|}{ Phase II, days 29-56 } \\
\hline$A D G, g$ & $725 \pm 22$ & $778 \pm 19$ & 5 & 0.772 \\
\hline ADFI, g & $1884 \pm 29$ & $1925 \pm 30$ & 33 & 0.964 \\
\hline FCR & $2.473 \pm 0.031$ & $2.601 \pm 0.052$ & 0.039 & 0.312 \\
\hline \multicolumn{5}{|c|}{ Phase III, days 57-84 } \\
\hline$A D G, g$ & $790 \pm 21$ & $814 \pm 27$ & 10 & 0.045 \\
\hline ADFI, g & $2013 \pm 13$ & $2095 \pm 14$ & 25 & 0.052 \\
\hline FCR & $2.652 \pm 0.067$ & $2.472 \pm 0.106$ & 0.039 & 0.334 \\
\hline \multicolumn{5}{|c|}{ Overall, days 0-84 } \\
\hline$A D G, g$ & $733 \pm 19$ & $784 \pm 25$ & 8 & 0.042 \\
\hline ADFI, $g$ & $1881 \pm 22$ & $1854 \pm 16$ & 14 & 0.502 \\
\hline FCR & $2.567 \pm 0.039$ & $2.491 \pm 0.077$ & 0.037 & 0.156 \\
\hline
\end{tabular}

1 treatments: basal diet (CON) and diet supplemented with $2 \%$ poppy seed meal (PSM); SEM - standard error of means; ADG - average daily gain, ADFI - average daily feed intake, FCR - feed conversion ratio effect of SBM and PSM present in the meal as PSM had lower water absorption capacity but higher fat absorption capacity than SBM. Previously, Bayram et al. (2006) reported that 25\% of PSM significantly increased BW gain of broilers. Statham (1984) in a trial on growing pigs fed diets based on SBM $(18.5 \%)$ and solvent-extracted PSM (25-27\%) found indistinguishable growth rates at the same lysine:energy ratio, indicating that PSM and SBM had similar lysine availability, and that PSM did not reduce the growth. The results of the present study are in line with the finding of Statham (1984) as we found no detrimental effect on growth performance. What is more, we have rather observed a significant increase in BW gain during the last phase and total weight gain during the whole feeding trial. There is, however, very limited research on the performance of pigs receiving the PSM-supplemented diet. On the other hand, inconsistent results due to the variation in the amount of PSM dosage, different animal models and differences in dietary composition are shown in the literature. For example, in the study by Bayram and Akinci (1998) conducted on growing Japanese quails fed diet supplemented with PSM up to $20 \%$ any effect on growth performance was shown. Also, Yldz et al. (2004) did not observe any effect on BW, live-weight gain and feed consumption by substitution of $20 \%$ of SBM by PSM. Similarly, Akyildiz (1984) reported the inclusion of PSM and poppy seed cake at 8 to $16 \%$ in broiler diets failed to prove any differences in daily weight gain and feed intake (replacing from 50 to $100 \%$ of CSM). However, the inclusion of PSM (up to $15 \%$ in the diet) together with yeast culture (Saccharomyces cerevisiae) $(0.10 \%)$ had some positive effects on egg weight and eggshell quality parameters (eggshell thickness) and no adverse effects on egg production and feed efficiency (Küçükersan et al., 2009). Besides, in another study by Statham (1984) it was stated that poppy seeds, through oil extraction or digestive process, may break free alkaloids, which in turn can impede growth performance. Also, Eklund and Ågren (1975) and Statham (1984) characterized PSM proteins as low-quality ones due to low level of lysine content. Nevertheless, it appears that PSM can be combined with other lysine-rich feedstuffs which would provide a similar outcome as SBM. Similar results were observed on other oilseed meals, e.g., canola meal had positive effect on ADG and ADFI in growing-finishing pigs (Seneviratne et al., 2010), and RSM (70, 140 and $210 \mathrm{~g}$ ) fed to growing-finishing pigs had no detrimental effects on ADG and ADFI (McDonnell et al., 2010). 
In comparison to pigs fed $\mathrm{CON}$ diet, pigs fed PSM-supplemented diet had significantly greater digestibility of DM at days 56 and $84(P=0.037$ and $P=0.048$, respectively) but $\mathrm{N}$ digestibility was unaffected during the whole experimental period (Table 4). In general, information about the nutrient digestibility of PSM is scarce. Yun et al. (2018) observed no significant effect on apparent total tract digestibility (ATTD) of DM and $\mathrm{N}$ after the inclusion of RSM and canola meal used as an alternative to SBM. Similarly, in our study also no significant differences were observed in $\mathrm{N}$ digestibility between the treatments throughout the whole experiment. This indicated that unsaturated lipids may be more easily digested than saturated lipids (Scheeder et al., 2003). But still, nutrient digestibility of PSM remains a major concern to be explored.

Table 4. Effect of dietary supplementation of poppy seed meal on nutrient digestibility in growing-finishing pigs

\begin{tabular}{|c|c|c|c|c|}
\hline \multirow{2}{*}{ Indices } & \multicolumn{2}{|l|}{ Treatments $^{1}$} & \multirow{2}{*}{ SEM } & \multirow{2}{*}{$P$-value } \\
\hline & $\mathrm{CON}$ & PSM & & \\
\hline \multicolumn{5}{|c|}{ Phase I, days 0-28 } \\
\hline DM & $73.20 \pm 2.51$ & $75.92 \pm 2.52$ & 0.73 & 0.995 \\
\hline $\mathrm{N}$ & $75.02 \pm 2.02$ & $77.7 \pm 1.59$ & 0.77 & 0.546 \\
\hline \multicolumn{5}{|c|}{ Phase II, days 29-56 } \\
\hline DM & $75.52 \pm 1.03$ & $76.13 \pm 0.44$ & 0.28 & 0.037 \\
\hline $\mathrm{N}$ & $71.39 \pm 1.21$ & $70.45 \pm 1.82$ & 0.64 & 0.305 \\
\hline \multicolumn{5}{|c|}{ Phase III, days 57-84 } \\
\hline $\mathrm{DM}$ & $71.97 \pm 0.76$ & $75.27 \pm 1.07$ & 0.36 & 0.048 \\
\hline $\mathrm{N}$ & $66.5 \pm 1.35$ & $67.34 \pm 1.18$ & 0.42 & 0.731 \\
\hline
\end{tabular}

${ }^{1}$ treatments: basal diet (CON) and diet supplemented with $2 \%$ poppy seed meal (PSM); SEM - standard error of means; DM - dry matter; $\mathrm{N}$ - nitrogen

There was no effect of PSM dietary addition on faecal microbiota $(P>0.05)$ throughout the whole experiment in comparison to the CON treatment (Table 5). Caridi (2002) reported different species of Lactobacillus having an inhibitory effect on E. coli. So, an increase in Lactobacillus count may reduce $E$. coli count by nutrient utilization competition or by producing lactic acid in the digestive system. But in the present study it was revealed that dietary inclusion of PSM in finishing pigs had no significant effect on the faecal microbiota of Lactobacillus counts and E. coli count during the overall experiment. Until now, there is no investigation on the dietary inclusion of PSM on the faecal microbiota counts in pigs. Hence, more studies are needed with different levels of PSM to know the exact cause of the substantial change absence in the faecal microbiota.
Table 5. Effect of dietary supplementation of poppy seed meal on faecal microflora in growing-finishing pigs, $\log _{10} \mathrm{CFU} / \mathrm{g}$

\begin{tabular}{lllll}
\hline \multirow{2}{*}{ Indices } & Treatments $^{1}$ & \multirow{2}{*}{ SEM } & P-value \\
\cline { 2 - 5 } & CON & PSM & & \\
\hline Phase I (days 0-28) & & & & \\
$\quad$ Lactobacillus & $7.36 \pm 0.07$ & $8.14 \pm 0.15$ & 0.07 & 0.2360 \\
$\quad$ E. coli & $4.65 \pm 0.22$ & $5.82 \pm 0.32$ & 0.23 & 0.5451 \\
Phase II (days 29-56) & & & & \\
$\quad$ Lactobacillus & $7.51 \pm 0.05$ & $8.20 \pm 0.15$ & 0.07 & 0.1130 \\
$\quad$ E. coli & $6.97 \pm 0.20$ & $7.18 \pm 0.27$ & 0.18 & 0.6368 \\
Phase III (days 57-84) & & & & \\
$\quad$ Lactobacillus & $7.59 \pm 0.04$ & $8.27 \pm 0.13$ & 0.06 & 0.1026 \\
E. coli & $7.06 \pm 0.11$ & $7.24 \pm 0.18$ & 0.05 & 0.4200 \\
\hline
\end{tabular}

${ }^{1}$ treatments: basal diet (CON) and diet supplemented with $2 \%$ poppy seed meal (PSM); SEM - standard error of means

The dietary supplementation of PSM exhibited no significant differences $(P>0.05)$ in the protein, glucose, WBC, RBC and lymphocytes concentrations in whole blood samples collected in all phases of the experimental period (Table 6). However, there is no other results from other studies to compare and demonstrate the reason for such an outcome.

Table 6. Effect of dietary supplementation of poppy seed meal on blood profile in growing-finishing pigs

\begin{tabular}{|c|c|c|c|c|}
\hline \multirow{2}{*}{ Indices } & \multicolumn{2}{|l|}{ Treatments $^{1}$} & \multirow{2}{*}{ SEM } & \multirow{2}{*}{$P$-value } \\
\hline & $\mathrm{CON}$ & PSM & & \\
\hline \multicolumn{5}{|c|}{ Phase I, (days 0-28) } \\
\hline protein, g/dl & $6.00 \pm 0.07$ & $5.83 \pm 0.11$ & 0.11 & 0.3739 \\
\hline glucose, mg/dl & $89.0 \pm 3.1$ & $88.8 \pm 5.4$ & 4.6 & 0.2341 \\
\hline WBC, $10^{3} / \mu \mathrm{l}$ & $19.40 \pm 2.6$ & $18.99 \pm 2.0$ & 2.49 & 0.6086 \\
\hline RBC, $10^{6} / \mu \mathrm{l}$ & $6.94 \pm 0.2$ & $6.87 \pm 0.2$ & 0.23 & 0.6867 \\
\hline lymphocyte, \% & $67.0 \pm 3.4$ & $62.6 \pm 2.8$ & 3.4 & 0.6526 \\
\hline \multicolumn{5}{|c|}{ Phase II, days 29-56 } \\
\hline protein, g/dl & $6.42 \pm 0.13$ & $6.55 \pm 0.14$ & 0.15 & 0.9582 \\
\hline glucose, mg/dl & $75.5 \pm 1.4$ & $74.3 \pm 0.8$ & 1.1 & 0.2142 \\
\hline WBC, $10^{3} / \mu \mathrm{l}$ & $23.57 \pm 2.25$ & $20.83 \pm 1.80$ & 1.49 & 0.6361 \\
\hline RBC, $10^{6} / \mu \mathrm{l}$ & $6.64 \pm 1.16$ & $7.12 \pm 0.22$ & 0.16 & 0.4973 \\
\hline lymphocyte, \% & $66.1 \pm 1.50$ & $62.0 \pm 2.90$ & 2.4 & 0.1745 \\
\hline \multicolumn{5}{|c|}{ Phase III, days 57-84 } \\
\hline protein, $\mathrm{g} / \mathrm{dl}$ & $6.87 \pm 0.11$ & $6.85 \pm 0.15$ & 0.08 & 0.5356 \\
\hline glucose, mg/dl & $88.0 \pm 2.07$ & $82.7 \pm 1.12$ & 1.6 & 0.2025 \\
\hline WBC, $10^{3} / \mu \mathrm{l}$ & $17.16 \pm 1.92$ & $19.05 \pm 1.49$ & 2.08 & 0.5874 \\
\hline RBC, $10^{6} / \mu \mathrm{l}$ & $7.46 \pm 0.08$ & $7.34 \pm 0.14$ & 0.07 & 0.2378 \\
\hline lymphocyte, \% & $52.6 \pm 2.52$ & $54.4 \pm 3.70$ & 2.3 & 0.4211 \\
\hline
\end{tabular}

${ }^{1}$ treatments: basal diet (CON) and diet supplemented with $2 \%$ poppy seed meal (PSM); SEM - standard error of means; WBC - white blood cells; RBC - red blood cells

\section{Conclusions}

Based on the obtained results, it can be concluded that the poppy seed meal (PSM) addition can be used in swine nutrition to improve growth 
performance and dry matter digestibility. However, a future investigation should be focused on the mechanism of action and understanding the effect of different concentrations of PSM in the swine diet.

\section{Conflict of interest}

The Authors declare that there is no conflict of interest.

\section{References}

Akinci Z., Bayram I., 2003. Effects of poppy seed meal on egg production and hatching results in quail (Coturnix coturnix japonica). Res. Vet. Sci. 75, 141-147, https://doi.org/10.1016/ s0034-5288(03)00054-7

Akyildiz A.R., 1984. Poppy seed oil meal as a source of protein in rations for broilers. Doga Bilim Dergisi, D1, 8, 87-93

AOAC International, 2010. Official Methods of Analysis of AOAC International. Current through revision 3. $18^{\text {th }}$ Edition. Gaithersburg, MD (USA)

Azcan N., Ozturk Kalender B., Kara M., 2004. Investigation of Turkish poppy seeds and seed oils. Chem. Nat. Compd. 40, 370-372, https://doi.org/10.1023/B:CONC.0000048250.81843.0a

Bayram I., Akinci Z., 1998. The effect of poppy seed meal added to quail rations on performance (in Turkish). Vet. Fak. Derg, Ankara. Univ. 45, 305-311, https://doi.org/10.1501/ Vetfak_0000000588

Bayram İ., Çetingül I.S., Yardımcı M., Şahin E.H., Akkaya A.B., Uyarlar C., 2008. Effects of poppy seed oil supplementation in diets on egg production, egg quality and some blood parameters in laying hens. Kocatepe Vet. J.1, 37-42

Bayram I., Midilli M., Bozkurt Z.A., Karadas E., Koken T., 2006. Effect of poppy seed meal in broiler diets. Indian Vet. J. 83, 1186-1189

Caridi A., 2002. Selection of Escherichia coli-inhibiting strains of Lactobacillus paracasei subsp. paracasei. J. Ind. Microbiol. Biotechnol. 29, 303-308, https://doi.org/10.1038/ sj.jim. 7000300

Eklund A., Ågren G., 1975. Nutritive value of poppy seed protein. J. Am. Oil Chem. Soc. 52, 188-190, https://doi.org/10.1007/ BF02672167

FAS (Foreign Agriculture Service), 2021. Oilseeds: World Markets and Trade. United States Department of Agriculture. Washington, DC (USA) (available on-line: https://www.fas.usda.gov/data/ oilseeds-world-markets-and-trade)

Kim S.W., Less J.F., Wang L., Yan T., Kiron V., Kaushik S.J., Lei X.G., 2019. Meeting global feed protein demand: challenge, opportunity, and strategy. Annu. Rev. Anim. Biosci. 7, 221-243, https://doi.org/10.1146/annurev-animal-030117-014838
Küçükersan S., Yeşilbağ D., Küçükersan K., 2009. Using of poppy seed meal and yeast culture (Saccharomyces cerevisiae) as an alternative protein source for layer hens. Kafkas. Univ. Vet. Fak. Derg. 15, 971-974

McDonnell P., O'Shea C., Figat S., O'Doherty J.V., 2010. Influence of incrementally substituting dietary soya bean meal for rapeseed meal on nutrient digestibility, nitrogen excretion, growth performance and ammonia emissions from growingfinishing pigs. Arch. Anim. Nutr. 64, 412-424, https://doi.org/1 0.1080/1745039X.2010.496947

Nergiz C., Ötles S., 1994. The proximate composition and some minor constituents of poppy seeds. J. Sci. Food. Agric. 66, 117-120, https://doi.org/10.1002/jsfa.2740660202

NRC (National Research Council), 2012. Nutrient Requirements of Swine. $11^{\text {th }}$ Revised Edition. The National Academies Press. Washington, DC (USA), https://doi.org/10.17226/13298

Özcan M.M., Atalay C., 2006. Determination of seed and oil properties of some poppy (Papaver somniferum L.) varieties. Grasas aceites 57, 169-174, https://doi.org/10.3989/gya.2006.v57. i2.33

Patsios S.I., Dedousi A., Sossidou E.N., Zdragas A., 2020. Sustainable animal feed protein through the cultivation of YARROWIA lipolytica on agro-industrial wastes and by-products. Sustainability 12, 1398, https://doi.org/10.3390/su12041398

Scheeder M.R.L., Gumy D., Messikommer R., Wenka C., Lambelet P., 2003. Effect of PUFA at sn-2 position in dietary triacylglycerols on the fatty acid composition of adipose tissues in non-ruminant farm animals. Eur. J. Lipid. Sci. Technol. 105, 74-82, https://doi.org/10.1002/ejtt.200390020

Seneviratne R.W., Young M.G., Beltranena E., Goonewardene L.A., Newkirk R.W., Zijlstra R.T., 2010. The nutritional value of expeller-pressed canola meal for grower-finisher pigs. J. Anim. Sci. 88, 2073-2083, https://doi.org/10.2527/jas.20092437

Statham M., 1984. Poppy seed meal (Papaver somniferum) as a protein source for growing pigs. Aust. J. Exp. Agric. Anim. Husb. 24, 170-173, https://doi.org/10.1071/EA9840170

UN (United Nations), 1999. E/RES/1999/32: International regulation and control of trade in poppy seeds. UN Economic and Social Council. Geneva (Switzerland)

Yldz A.O., Olgun O., Cufadar Y., Parlat S.S., 2004. Effect of replacing soybean meal with poppy seed (Papaver somniferum L.) meal as an alternative protein source on performance and carcass traits in Japanese quails. Hayvanclk Arastirma Dergisi 14, 73-77

Yun H.M., Lei X.J., Lee S.I., Kim I.H., 2018. Rapeseed meal and canola meal can partially replace soybean meal as a protein source in finishing pigs. J. Appl. Anim. Res. 46, 195-199, https://doi. org/10.1080/09712119.2017.1284076 